ADRIANNA WOROCH

Instytut Filmu, Mediów i Sztuk Audiowizualnych Uniwersytet im. Adama Mickiewicza w Poznaniu

\title{
W świecie kolorowej (anty)utopii. O animowanych cyborgach $w$ Kongresie Ariego Folmana
}

\begin{abstract}
Woroch Adrianna, $W$ świecie kolorowej (anty)utopii. O animowanych cyborgach $w$ Kongresie Ariego Folmana [In a world of a colorful (anti)utopia. About animated cyborgs in The Congress by Ari Folman]. "Images" vol. XXVIII, no. 37. Poznań 2020. Adam Mickiewicz University Press. Pp. 141-150. ISSN 1731-450X. DOI 10.14746/i.2020.37.08.

The article focuses on pointing out the functions of using animation technique and elements of the science fiction genre in Ari Folman's The Congress from 2013. The film, which is loosely based on the short story The Futurological Congress by Stanisław Lem, balances on the edge of various genres, using the techniques of both live action film and computer animation. Folman proposes a glamorous, colorful vision of an (anti)utopian future, in which pharmacologically-modified cyborg-people participate in a collective hallucination, which is an alternative reality to the post-apocalyptic real world. The director makes several significant changes to the original, thanks to which he introduces a universal message and asks questions which seem far more relevant in the context of both contem porary culture and the environmental crisis that can no longer be ignored (although the issue of an impending natural disaster was also important in Lem's works).
\end{abstract}

KeYwords: Ari Folman, Stanislaw Lem, The Congress, animation, technology, anti-utopia, science fiction

Pięć lat po Walcu z Baszirem (2008) Ari Folman ponownie zrealizował animację - Kongres, bazującą na opowiadaniu Stanisława Lema. Reżyser, zamiast jednak starać się dokładnie odwzorować pierwowzór, postanowił przetransponować na język ruchomych obrazów jedynie niektóre rozwiązania fabularne oraz surrealny nastrój opowiadania Kongres futurologiczny. Technika animacji umożliwiła Folmanowi wytworzenie pomostu pomiędzy rzeczywistością a narkotycznymi wizjami bohaterów. Z jednej strony pozwoliła ona bowiem oddać stany emocjonalne protagonistki, z drugiej - pozostała silnie związana z realnością. Animacja nie stanowi więc w Kongresie zaprzeczenia mimesis ani nie przesądza jednoznacznie o odbiorze filmu w kategoriach gatunku science fiction, jest natomiast maską dla postapokaliptycznej rzeczywistości - kolorową alternatywą dla szarego życia w nędzy i chorobie.

Kongres składa się z dwóch linii narracyjnych - podobnie jak pierwowzór literacki składa się z dwóch części (opowieści z pierwszoosobową narracją oraz dziennika głównego bohatera). Pierwsza z płaszczyzn filmowej narracji to część aktorska. Jest to historia dobiegającej wieku średniego aktorki - Robin Wright (postmodernistycznym zwyczajem reżyser obnaża tworzywo filmowe, stosując element metafilmowy - w roli głównej bohaterki obsadzona została Robin Wright), która
Images vol. XXVIII/no. 37

Poznań 2020

ISSN 1731-450X 
decyduje się na utrwalenie swojego wizerunku w postaci cyfrowego awatara. Chcąc poświęcić więcej czasu choremu synowi, podpisuje kontrakt z wytwórnią Miramount (łącząc nazwy dwóch ważnych wytwórni filmowych - Miramax Films oraz Paramount Pictures, Folman dopuszcza się tu kolejnej metafilmowej gry - tym razem słownej) i tym samym wyraża zgodę, aby cyfrowa, odmłodzona (i wiecznie młoda) wersja jej samej występowała w filmach sygnowanych jej nazwiskiem przez najbliższych dwadzieścia lat.

Następnie akcja przenosi się o rzeczone dwadzieścia lat w przyszłość. W tej części twórca zastosował technikę animacji w klasycznym stylu studia braci Fleischerów[1] czy Texa Avery’ego. Wright zostaje zaproszona jako gość specjalny na kongres futurologów (warto zauważyć, że to wydarzenie fabularne w filmie nawiązuje bezpośrednio do tytułu opowiadania Lema i zwiastuje, że dalsza część dzieła w dużo większym stopniu bazować będzie na pierwowzorze literackim aniżeli część aktorska), organizowany przez wytwórnię Miramount. Kiedy przekracza granicę miasta Abrahama City, w którym ma się odbywać sympozjum, realność ustępuje miejsca fantazji, a animowana postać aktorki wkracza w psychodeliczny, kolorowy świat, zdominowany przez koncern kinematograficzny i środki farmaceutyczne.

Bohaterka próbuje poznać zasady rządzące narkotyczną rzeczywistością, aby wkrótce przekonać się, że takowe nie istnieją. Istnieją natomiast jedynie emocje, ambicje, pragnienia, które zaspokoić można, łykając tajemniczą pigułkę. W Abrahama City każdy może być kim chce - zarówno w sensie metaforycznym, jak i dosłownym. Zażywając specjalny preparat, bohaterowie zmieniają na chwilę swój wygląd i stają się ikonami popkultury, postaciami z filmów czy mitologii. Nie wszystkim jednak podoba się hegemonia wytwórni Miramount. Podczas kongresu w mieście wybuchają zamieszki. Z rewolucyjnego chaosu bohaterkę ratuje Dylan, który przez ostatnie dwie dekady pracował w Miramount w dziale zajmującym się animowaniem jej wirtualnego awatara. Para odnajduje w swoich ramionach jednorazowe spełnienie, po czym Robin decyduje się powrócić do „prawdziwego świata”, by odszukać swojego syna.

Te dwie płaszczyzny - film aktorski i animacja - spójne są także z rytmem fabuły. W scenach aktorskich zachowany jest związek przyczynowo-skutkowy, konsekwentnie prowadzona narracja wiedzie odbiorcę od punktu A do punktu B. Opowieść toczy się stosunkowo wolno, bez dynamicznych zwrotów akcji. Jest to raczej intymny dramat

[1] Jedna z najsłynniejszych postaci amerykańskich kreskówek - Betty Boop - jest dziełem Grima Natwicka, pracującego wówczas właśnie dla Fleischer Studios. Wiele postaci z Kongresu przejawia charakterystyczny dla kreskówek z lat dwudziestych i trzydziestych wygląd: duże, okrągłe oczy (tak zwane pie eyes) i elastyczne, rozciągliwe kończyny bez wyraźnie zarysowanych stawów (stąd też sposób rysunku znany z serii o Myszce Mickey, Popeyu czy Króliku Oswaldzie, często z tego powodu określany jest mianem rubber hose animation). Postaci widoczne w tle są często w ruchu, niejednokrotnie wykonują zapętlone czynności, co także ma swoje źródła w filozofii dawnej animacji, której podstawą było dostarczanie widzowi ciągłych bodźców. 


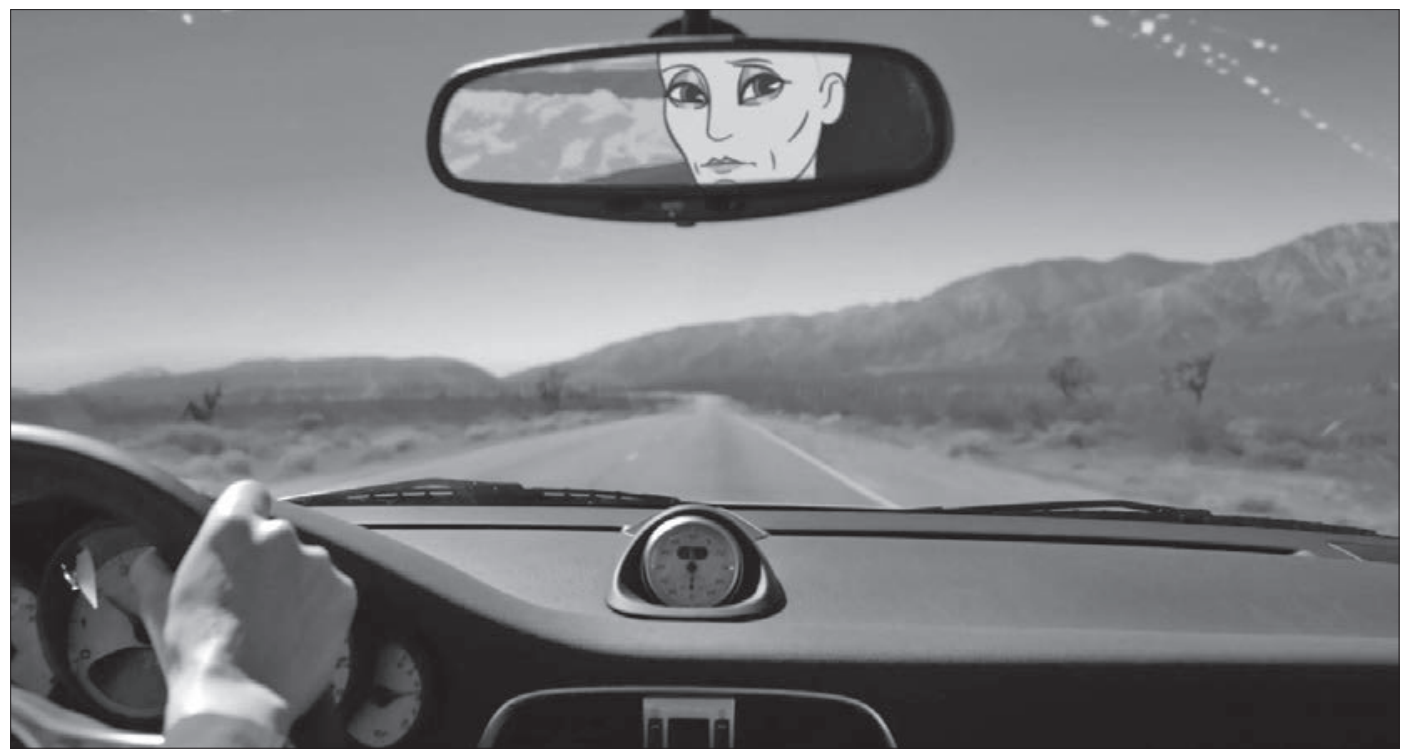

rodzinny, przedstawiony z perspektywy obiektywnej kamery. Dialogi pełnią funkcję informacyjną, wprowadzają widza w tok fabuły i nie wymagają głębszej refleksji nad ich ukrytym znaczeniem. Część ta jest więc nastawiona przede wszystkim na realizm, dramaturgię i klasycznie rozumianą, klarowną fabułę. Zupełnie odwrotnie dzieje się w sekwencjach animowanych. Te zostają zdominowane przez porządek fantasmagoryczny - reżyser rezygnuje z mimetycznego przedstawiania zdarzeń na rzecz urzekających wizualnie, surrealistycznych halucynacji bohaterów. W świecie animowanym akcja przyspiesza. Pojawiają się różne wątki, które jednak często urwane zostają w połowie. Nie ma tu spójnej wizji świata, wyraźnej granicy pomiędzy fantazją a realnością. Widz nie otrzymuje od reżysera narzędzi, za pomocą których mógłby odczytać przedstawioną na ekranie rzeczywistość. Pozostaje jedynie poddać się porządkowi narkotycznego snu, nie próbując rozgraniczać prawdy od wytworów umysłu. Dialogi także niewiele wyjaśniają. Są raczej poetycką refleksją, wpasowującą się w otaczającą bohaterów fantastyczną (nie)rzeczywistość.

Świat Lema, w którym gwiezdny podróżnik Ijon Tichy zostaje uwięziony w wielopoziomowym labiryncie własnych halucynacji, podporządkowany został producentom środków farmaceutycznych. Folman dokonuje w stosunku do pierwowzoru literackiego znaczącej transakcentacji, choć zagadnienie halucynogennych specyfików jest w adaptacji wciąż obecne. Przede wszystkim jednak główną potęgą jest w Kongresie wytwórnia Miramount - bezduszna fabryka ruchomych obrazków, kontrolująca cały przemysł filmowy, włącznie z jego odbiorcami. Wyraźna w opowiadaniu satyra na komunizm zastąpiona została u Folmana satyrą o nieco pratchettowskim rodowodzie, demonizującą świat Hollywoodu. Dyktat Miramountu oparty jest na bezgranicznym zaufaniu do technologii komputerowych oraz kształtującej współczesną
Il. 1. Kongres (2013), reż. Ari Folman; pierwsze chwile po przekroczeniu przez Robin granicy Abrahama City. Jest to jedno z kilku ujęć w filmie łączących dwa porządki - animację oraz film aktorski 
kulturę fascynacji młodością, z czym wiąże się również podatność na wszelkie - także farmakologiczne - rozwiązania przeciwdziałające stabuizowanemu starzeniu się. Ten mit wiecznej młodości i nieprzemijającej urody poza głównym wątkiem fabularnym poruszany jest także w warstwie dźwiękowej filmu. Na niediegetycznej ścieżce dźwiękowej, skomponowanej przez Maxa Richtera, znalazła się śpiewana przez Robin Wright psychodeliczna rockowa ballada, będąca uwspółcześnioną pod względem linii melodycznej wersją Forever Young Boba Dylana. Przeniesienie akcentów na metafory bliższe współczesnemu widzowi sam reżyser tłumaczy w ten sposób:

[...] chciałem współczesnej opowieści, osadzonej w innym świecie, pochylającej się nad innym rodzajem dyktatury. Komunizm to przeszłość, to wszystko działo się 23 lata temu. A ja chciałem czegoś lepiej identyfikującego nasze czasy, dokładniejszego. Na tym poziomie książka przemawiała do mnie jako do artysty. Alegoria komunizmu jest u Lema silna, ale to także opowieść o kryzysie tożsamości - rozumianym dosłownie i metaforycznie. O wolnej woli. Chciałem to lepiej wyeksponować[2].

Ów kryzys tożsamości dotyka każdego z uczestników „chemicznej imprezy”[3]. Kiedy Robin po raz pierwszy przekracza granicę animowanego świata i udaje się do siedziby Miramount, gdzie ma odbyć się kongres, zauważa, że niektórzy goście popijają tajemniczy napój z małych fiolek i na kilka sekund zmieniają postać. Folman tłumaczy swoje zainteresowanie kwestią tożsamości w wywiadzie z Pawłem T. Felisem: „Mówimy o tożsamości: jej traceniu i odzyskiwaniu. Ale też stawiamy pytanie, czym w ogóle jest tożsamość, zwłaszcza w świecie, w którym ludzie za pomocą środków chemicznych funkcjonują głównie w swoich fantazjach, nie rozróżniają halucynacji od rzeczywistości”[4].

Reżyser zaznacza, że w filmie pojawiają się rozważania dotyczące statusu tożsamości - chwiejnej i niepewnej, poddawanej ciągłym przekształceniom. Sytuacja ulega jednak zmianie w dalszej części filmu. Robin doznaje halucynacji, w której zostaje zastrzelona przez szefa Miramount - Jeffa Greena. W konsekwencji, uznana za niepoczytalną, zostaje zamrożona w ciekłym azocie. Kiedy jednak po latach dochodzi do jej odmrożenia, znajduje się w całkiem innym świecie. Przyjmowanie cudzych tożsamości stało się normą, a nie jedynie stanem przejściowym. Ludzie przyjmują role, chowają się pod maskami postaci religijnych i ikon popkultury. Choć „chowają” to być może w tym przypadku nieodpowiednie słowo, gdyż paradoksalnie - te maski służą wolności totalnej, całkowitemu obnażeniu instynktów, pierwotnej natury, podporządkowanej namiętnościom i rytmowi przyrody.

[2] M. Walkiewicz, WYWIAD: Twórca „Walca z Baszirem" $i$ „Kongresu” specjalnie dla Filmwebu, <http:// www.filmweb.pl/article/WYWIAD\%3A+Tw\% $\mathrm{C}_{3} \% \mathrm{~B}_{3} \mathrm{r}$ $\mathrm{ca}+\% 22 \mathrm{Walca}+\mathrm{z}+\mathrm{Baszirem} \% 22+\mathrm{i}+\% 22$ Kongresu\%22+ specjalnie+dla+Filmwebu-98825>, dostęp: 17.01.2020.
[3] W ten sposób bohaterowie filmu określają egzystowanie w sztucznym, chemicznym świecie.

[4] P.T. Felis, Walc z Lemem - wywiad $z$ Arim Folmanem, <http://wyborcza.pl/1,75475,13941037,Walc_z_ Lemem__wywiad_z_Arim_Folmanem.

html\#ixzz3xVhECoEW >, dostęp: 17.01.2020. 
Folman proponuje ekstrawagancką, a jednocześnie niepozbawioną melancholii wizję (anty)utopijnej przyszłości. W tym świecie jutra farmaceutyki umożliwiają kontrolę ludzkiej biochemii, manipulowanie substancjami w organizmie, odpowiedzialnymi za odczuwanie poszczególnych emocji, produkcję hormonów i percepcję. Każdy może kreować siebie, zmieniać swoje cechy fizyczne, stać się greckim bogiem, angielską królową czy amerykańskim celebrytą. Ponadto reżyser tworzy też nowego, ulepszonego człowieka - pozbawionego wad i destrukcyjnych skłonności, głęboko wierzącego w powrót idei hipisowskich. W Nowym Jorku z wizji Folmana po drapaczach chmur wiją się łodygi gigantycznych roślin, ludzie są równi, pozbawieni ego, koegzystują z naturą, nie wszczynają kłótni ani nie rozpoczynają wojen.

W takiej wizji (poza drugoplanową refleksją nad ułomnością zdolności percepcyjnych człowieka, zależnych całkowicie od aspektów biologicznych i chemicznych) zakwestionowane zostaje tradycyjne, nowożytne rozumienie roli maski:

Człowiek współczesny pragnie „zdjąć maskę”, aby nareszcie „być sobą”. Zdarza się też, że z kogoś „opadnie maska” w innym znaczeniu, a wtedy - cóż za okropny widok! Naszym oczom ukazuje się niecywilizowana, nieludzka i wroga ludziom istota. Najogólniej rzecz biorąc, sądzimy współcześnie, że maska służy ukryciu tego, kto ją nosi. Rzeczywiście, dzieje się tak w przypadku przestępcy. A gdy, nawiązując do archaicznej tradycji, maskujemy się w karnawale, nagle stajemy się dzikusami, którymi nigdy nie odważamy się być bez przebrania. Tak więc maski, zarówno metaforyczne, jak i materialne, pełnią dziś funkcję wyłącznie negatywną. Współczesna kultura zredukowała je do narzędzi służących skrywaniu się[5].

W Kongresie natomiast maska umożliwia nie ukrywanie swej tożsamości, co wręcz przeciwnie - jej wydobycie.

Tak rozumiane pojęcie maski można by w kontekście dzieła Folmana zastąpić mającą swój rodowód w teoriach sztuki science fiction definicją cyborgizacji. Jak pisze Grażyna Gajewska w książce Arcy-nie-ludzkie: przez science fiction do antropologii cyborgów:

[...] logika powstawania cyborga opiera się na introjekcji i absorpcji. W akcie tym znoszona jest granica między tym, co naturalne, a tym, co sztuczne; między tym, co wewnętrzne, a zewnętrzne. Cyborg - już z założenia - nie może być rozmontowany na część naturalną i elektromechaniczną, gdyż wówczas przestałby być tym, kim jest, czyli ludzko-techniczną hybrydą, która funkcjonuje tylko dzięki zespoleniu tych elementów. W przypadku cyborga nie można zedrzeć sztuczności bez naruszenia osobowości, gdyż w akcie introjekcji chodzi właśnie o otoczenie jednego ciała przez drugie (np. mechaniczne) czy też włączenie do własnej świadomości obrazu innej postaci [...] w taki sposób, że staje się ona częścią naszej własnej tożsamości[6].

[5] K. Kerényi, Człowiek i maska, przeł. A. Kryczyńska-Pham, [w:] Antropologia widowisk. Zagadnienia i wybór tekstów, red. L. Kolankiewicz, wyd. II zm., popr. i rozsz., Warszawa 2010, s. 684.
[6] G. Gajewska, Arcy-nie-ludzkie: przez science fiction do antropologii cyborgów, Poznań 2010, s. 7-8. 
I choć Gajewska ma tu na myśli przede wszystkim tradycyjnie rozumiane hybrydy istoty biologicznej i maszyny, trudno oprzeć się wrażeniu, że Folman kierował się podobnymi założeniami. Poruszone wyżej zmiany tożsamości bohaterów Kongresu stanowią bowiem pełną realizację zaproponowanego przez badaczkę rozumienia cyborga jako tworu, w obliczu którego binarne podziały na „prawdziwe ja” i „udawane niby-ja" stają się pustymi, nieużytecznymi opozycjami. Mieszkańcy Abrahama City żyją w harmonii ze swoimi (co prawda uzyskanymi nie dzięki technologii, a farmakologii) awatarami. Nie sposób odróżnić ich dawnej, ludzkiej postaci od tej sztucznej, nabytej. Dalej Gajewska uzasadnia, dlaczego ingerencję technologii w ludzkie ciała i życia powinniśmy uznawać za naturalny proces reorganizacji naszego funkcjonowania, nie natomiast jako zewnętrzny dodatek:

Ponieważ ludzki umysł i ciało od dawna zmienia się pod wpływem stosowanych narzędzi (urządzenia wykonujące prace fizyczne, komputery dokonujące ilościowych obliczeń, środki farmakologiczne wspierające wydajność fizyczną, ale także pracę umysłową) i nieustannie przestraja na nowe sposoby funkcjonowania, to technologii nie można traktować jako czegoś zewnętrznego względem człowieka. Ona w coraz większym stopniu organizuje nasze życie i powoduje przesuwanie granic między tym, co naturalne a sztuczne[7].

Folman z przenikliwością dostrzega zmiany zachodzące we współczesnym świecie, lecz nie wywołują w nim jednoznacznej trwogi. W Kongresie podważona zostaje dawna autonomia cielesności, jej niezależność od sfery technologicznej czy farmakologicznej, jej prymarna pozycja wobec sztucznych tworów, wyrosłych spod palców programistów czy z probówek naukowców. Nie oznacza to jednak, że izraelski reżyser uznaje to za zwiastun nadchodzącej zagłady ludzkości. Stara się raczej unikać moralizatorstwa i jednostronności, czego przykładem jest jedna $\mathrm{z}$ ostatnich scen filmu, w której samowystarczalność ciała biologicznego zostaje podana w wątpliwość, a cyborgizacja wydaje się jedynym słusznym wyborem.

W poruszonej scenie Robin Wright połyka tabletkę mającą przenieść ją „na drugą stronę”, a więc pozwolić jej opuścić Abrahama City i powrócić do normalnej rzeczywistości. Wówczas kamera przyjmuje perspektywę point of view bohaterki. Kobieta mija ikony ze świata sztuki i popkultury - między innymi Wenus z obrazu Botticellego, Lizę Minelli w estradowym stroju z Kabaretu oraz Davida Bowiego we wcieleniu scenicznym Ziggy'ego Stardusta. Kilka ujęć później następuje przeskok montażowy z powrotem do świata rzeczywistego. Reżyser komponuje kadr w taki sposób, aby ustawienie postaci było niemal dokładnie takie samo jak w poprzednim, animowanym ujęciu. Kamera także nie zmienia ustawienia, widz wciąż obserwuje wydarzenia oczami protagonistki. Robin „odsłania maskę” (w sensie metafilmowym - w postaci techniki animacji), pod którą skrywa się rzeczywistość - plugawa, 


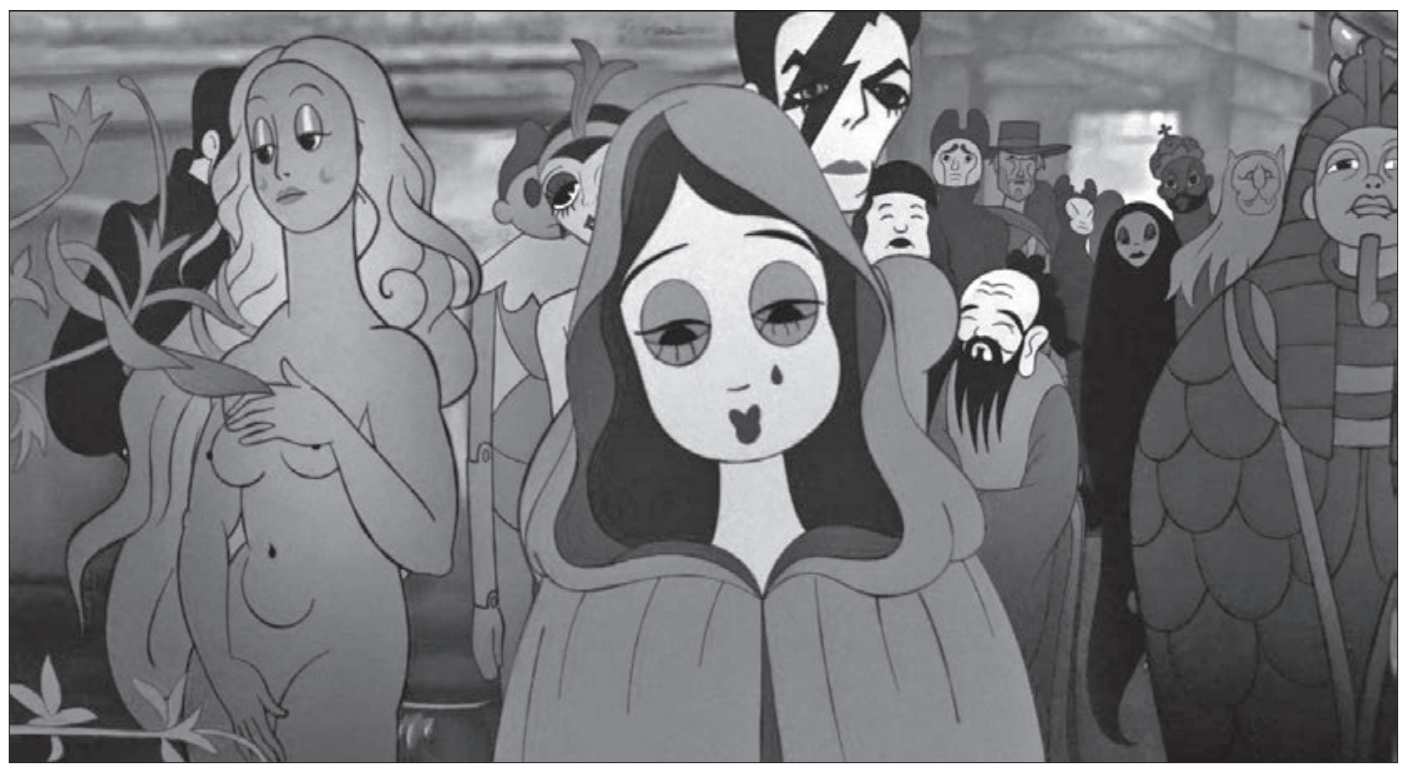

apokaliptyczna i rozczarowująca. Narkotyk przestaje działać; Wright przedziera się przez zahipnotyzowany tłum brudnych, nijakich ludzi, niewidzącym wzrokiem wpatrujących się w przestrzeń. Wenus okazuje się zaniedbaną kobietą w średnim wieku i zniszczonym ponczo, a Bowie - przeciętnym starszym panem z posępną miną. Chcąc uciec od tej przeciętności, od beznadziei, bólu i śmierci, którą widać w realnym świecie za każdym zakrętem, większość społeczeństwa decyduje się zażyć narkotyk i uczestniczyć w zbiorowej formie halucynacji.

Folman wydaje się faworyzować porządek animowanego świata iluzji. Choć zniekształcony chemicznymi substancjami, choć niepraw-
Il. 2. Kongres (2013), reż. Ari Folman; ujęcie tuż przed „zdjęciem animowanej maski” przez główną bohaterkę

Il. 3. Kongres (2013), reż. Ari Folman; przeskok do postapokaliptycznego świata rzeczywistego

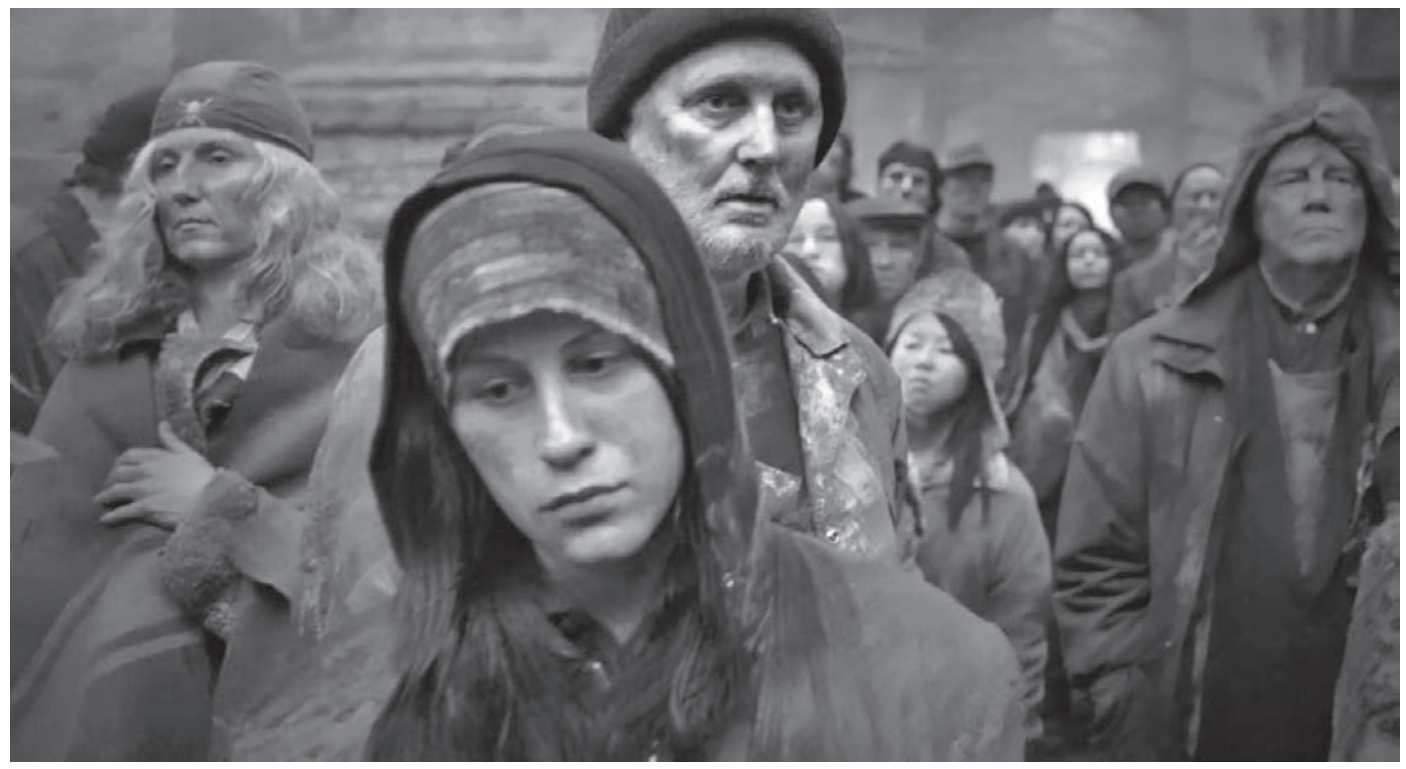


dziwy, to właśnie on daje ukojenie i stanowi jedyną nadzieję. To ten świat jest barwny, pełen olśniewających wizji, wspaniałych halucynacji - zrodzonych z potęgi wyobraźni i tylko w wyobraźni mogących egzystować. Reżyser kieruje w stronę odbiorcy retoryczne pytania: czy prawda ma znaczenie? Czy łatwiejsze rozwiązanie zawsze oznacza tchórzostwo? Czy powinniśmy, wbrew swoim pragnieniom, godzić się, w imię martyrologicznego poświęcenia, umierać w nędzy, zamiast żyć w imaginacyjnym mieście wiszących ogrodów i pięknych ludzi? Po trzykroć: nie. Ponadto, Folman zachęca także do zastanowienia się nad kwestią granic technologii i jej ingerencji w ludzki porządek życiowy. Podobne refleksje pojawiają się, w większym lub mniejszym stopniu, w każdym tekście Lema. Trzon swoich rozważań filozoficznych zawarł pisarz w serii pytań zawartych w zbiorze esejów Summa technologiae:

Kto powoduje kim? Technologia nami, czy też my - nią? Czy to ona prowadzi nas, dokąd chce, choćby do zguby, czy też możemy zmusić ją do ugięcia się przed naszym dążeniem? Ale co, jeśli nie myśl technologiczna określa owo dążenie? Czy zawsze jest tak samo, czy też sam stosunek „ludzkość - technologia" jest zmienny historycznie? Jeśli tak, dokąd zmierza ta wielkość niewiadoma? Kto zdobędzie przewagę, przestrzeń strategiczną dla cywilizacyjnego manewru, ludzkość dowolnie wybierająca $\mathrm{z}$ arsenału środków technologicznych do jej dyspozycji, czy też technologia, która automatyzacją zwieńczy proces obezludniania swych obszarów? Czy istnieją technologie do pomyślenia, lecz - teraz i zawsze nierealizowalne? Co by o takiej niemożliwości przesądzało - struktura świata, czy nasze ograniczenia?[8]

Zagadnienia związane z technologią zajmują więc obu twórców bardzo mocno. Lemowską niepewność i sceptycyzm co do przyszłości człowieka w świecie technologii (czy też przyszłości technologii w świecie ludzkim) reżyser Kongresu wydaje się jednak nieco łagodzić. Zupełnie niegroźna okazuje się bowiem animacja (a więc realizacja zagadnienia technologii na poziomie metafilmowym) obrazująca dobrodziejstwa rynku farmakologicznego (a więc technologię w formie stematyzowanej).

Technika animacji spełnia w filmie funkcję przekaźnika, bufora pomiędzy zewnętrzną rzeczywistością a chaosem panującym wewnątrz umysłu głównej bohaterki. Pozwala uzyskać dostęp do wizji i urojeń Robin, widzieć świat jej oczami, choć niekoniecznie poprzez zabieg subiektywnej kamery. Świat zmanipulowany i zniekształcony przez substancje chemiczne otwiera twórcy pole możliwości artystycznych. Odrealnione, jaskrawe kolory różnią się od rozwiązań zastosowanych w Walcu z Baszirem. Tam postaci charakteryzowały się mniej ekstrawaganckimi kształtami, rysami twarzy. Choć więc kreska w Kongresie jest bardzo fantazyjna i nierealistyczna, mimo wszystko zauważyć można pewien paradoks: technika animacji pomogła Folmanowi pogłębić filozoficzny wydźwięk filmu i nadać mu powagi, swego rodzaju elegancji. 
Być może gdyby reżyser zdecydował się nakręcić w pełni aktorski film science fiction, wzbogacony o komputerowe efekty i hybrydy ludzi-cyborgów, nie udałoby mu w tak złożony sposób poruszyć rozważań dotyczących kondycji człowieka i świata, a Kongres nie uchodziłby za dzieło wartościowe ani pod względem artystycznym, ani intelektualnym.

Dzięki technice animacji Folmanowi udało się również zachować jedno z podstawowych zainteresowań tematycznych gatunku $s f$, jakim jest ekologia. Bardzo często to wokół zagadnień środowiskowych krążą fabuły fantastyki naukowej. Wyrażają obawę przed niszczycielską siłą konsumpcjonizmu i globalizacji, prognozują stan świata po katastrofie ekologicznej, snują wizje alternatywnych rzeczywistości i wysuwają propozycje sposobów radzenia sobie w nowych warunkach. Kongres odzwierciedla również główne zainteresowania Lema (poza poruszonymi już kwestiami związanymi z ekologią, które pisarz regularnie inkorporuje do swoich opowiadań), związane z etyką, moralnością i tożsamością. Reżyser skupia się szczególnie na ostatnim zagadnieniu, silnie związanym ze wspomnianym wcześniej motywem maski, obecnym w sztuce filmowej i chętnie wykorzystywanym w produkcjach o psychoanalitycznych ambicjach. Wszyscy - zarówno na poziomie metafilmowym, jak i na poziomie fabuły - ukrywają prawdę. Reżyser ukrywa postapokaliptyczną, zaśmieconą rzeczywistość pod warstwą animacji. Bohaterowie natomiast odurzają się substancjami chemicznymi, chcąc choć na chwilę stać się kimś innym - czy to sławnym piosenkarzem, ikoną seksu, sławną aktorką czy też Jezusem. Nic nie jest takie, jakie się wydaje. Kłamstwo i kradzież tożsamości są usankcjonowanymi społecznie zachowaniami. Udawanie zostało doprowadzone do ekstremum, a pojęcia takie jak prawda czy rzeczywistość dawno straciły jakiekolwiek znaczenie. Bohaterowie żyją w tym postbiologicznym, animowanym świecie jak w próżni - bez przeszłości, bez jakiegokolwiek punktu odniesienia, poza czasem i przestrzenią. Tylko Robin, choć zaledwie na chwilę, decyduje się na powrót do rzeczywistego świata. Okazuje się on jednak skażony chorobą, brudem i ubóstwem. W tej perspektywie psychodeliczna kraina wyobraźni, gdzie karaluchy grają w karty, a nad centrum Nowego Jorku unosi się gigantyczny arbuz, wydaje się kuszącą alternatywą.

Felis P.T., Walc $z$ Lemem - wywiad $z$ Arim Folmanem, <http://wyborcza. pl/1,75475,13941037,Walc_z_Lemem___wywiad_z_Arim_Folmanem. html\#ixzz3xVhECoEW>, dostęp: 17.01.2020

Frelik P., Kultury wizualne science fiction, Kraków 2017

Gajewska G., Arcy-nie-ludzkie: przez science fiction do antropologii cyborgów, Poznań 2010

Kerényi K., Człowiek i maska, przeł. A. Kryczyńska-Pham, [w:] Antropologia widowisk. Zagadnienia i wybór tekstów, red. L. Kolankiewicz, wyd. II zm., popr. i rozsz., Warszawa 2010

Lem S., Summa technologiae, Kraków 2000 
Sitkiewicz P., Małe wielkie kino: film animowany od narodzin do końca okresu klasycznego, Gdańsk 2009

Walkiewicz M., WYWIAD: Twórca «Walca $z$ Baszirem» $i$ «Kongresu» specjalnie dla Filmwebu, <http://www.filmweb.pl/article/WYWIAD\%3A+Tw\%C3\%B3 $\mathrm{rca}+\% 22 \mathrm{Walca}+\mathrm{z}+$ Baszirem $\% 22+\mathrm{i}+\% 22$ Kongresu $\% 22+$ specjalnie $+\mathrm{dla}+$ Film webu-98825>, dostęp: 17.01.2020 